\title{
A Recent species of Frambocythere Colin, 1980 (Ostracoda, Crustacea) from a cave in South Korea; the first extant representative of a genus thought extinct since the Eocene
}

\author{
ROBIN J. SMITH ${ }^{*}$, JIMIN LEE ${ }^{2}$, YONG GEUN CHOI ${ }^{3}, \mathrm{CHEON}$ YOUNG CHANG ${ }^{2}$ \& JEAN-PAUL COLIN ${ }^{4}$ \\ ${ }^{1}$ Lake Biwa Museum, 1091 Oroshimo, Kusatsu, Shiga 525-0001, Japan \\ ${ }^{2}$ Daegu University, 15 Naeri-ri, Jillyang-up, Gyeongsan 712-714, South Korea \\ ${ }^{3}$ Yeongwol Cave Eco-Museum, 1121-15 Yeongwol-dong-ro, Kimsakgat-myeon, Yeongwol-gun, Gangwon-do 230-821, South Korea \\ ${ }^{4}$ Universidade de Lisboa, Faculdade de Ciências, Centro de Geologia, Campo Grande, C-6, $3^{\circ}$ 1749-016 Lisboa, Portugal, \\ and 3 Impasse des Biroulayres, 33610 Cestas, France \\ *Corresponding author (e-mail: smith@lbm.go.jp)
}

\begin{abstract}
The non-marine ostracod genus Frambocythere Colin, 1980 (Limnocytheridae, Timiriaseviinae) had a previously known stratigraphical range from the Albian (Lower Cretaceous) through to the Lutetian (middle Eocene). However, during surveys of Seongryu Cave in Uljin-gun Province, South Korea, specimens of an extant species of Frambocythere were recovered. This extends the stratigraphic range of the genus by more than 40 million years to the present, and the species is, therefore, considered to be a relict 'living fossil'. This newly described species is most similar in morphology to Frambocythere gr. tumiensis (Helmdach, 1978), reported from Thanetian (Paleocene) deposits of the Paris Basin. The living species was found in the hypogean realm, in contrast to the fossil species, which were all epigean. It is hypothesized that, like the genus Kovalevskiella Klein, 1963, which belongs to the same lineage, Frambocythere migrated from epigean to hypogean habitats. J. Micropalaeontol. 31(2): 131-138, July 2012.
\end{abstract}

KEYWORDS: Frambocythere, Eocene, Recent, hypogean, relict

\section{INTRODUCTION}

The genus Frambocythere Colin, 1980 (in Colin \& Danielopol, 1980) consists of nine described species/subspecies and some species in open nomenclature, ranging from the Albian to the middle Eocene. It is widely distributed from Africa, SW Europe, India and China (Hou et al., 1978; Colin \& Danielopol, 1980; Tambareau, 1984; Tambareau et al., 1991; Colin, 1993; 2011; Colin \& Dépêche, 1997; Bhandari \& Colin, 1999; Whatley \& Bajpaj, 2006). The genus belongs to the Kovalevskiella lineage (Limnocytheridae, Timiriaseviinae), which also includes the genera Kovalevskiella Klein, 1963, and Rosacythere Colin, 1980 (in Colin \& Danielopol, 1980). Of this lineage, only five species, all belonging to the genus Kovalevskiella, are extant, found in central and southeastern Europe and Turkey (Danielopol, 1965; 1969; 1970; Colin \& Danielopol, 1980; Karanovic, 2003; Özuluğ \& Yaltalier, 2008). All five extant species are considered to be primarily hypogean, although Kovalevskiella bulgarica (Danielopol, 1970) has been recovered from a stream in Turkey (Özuluğ \& Yaltalier, 2008). All other species of the lineage are extinct epigean species, typically found in lacustrine deposits.

During investigations of Seongryu Cave in Uljin-gun Province in South Korea, nine specimens of a living Frambocythere species were recovered and are the subject of this paper.

\section{LOCALITY, MATERIAL AND METHODS}

Seongryu Cave is a limestone cave in South Korea, and was designated as a Natural Monument (No. 155) of the Republic of Korea in 1963. The entrance of the cave is located at the riverside of the lower reaches of the Wangpicheon River $\left(36^{\circ} 57^{\prime} 21.87^{\prime \prime} \mathrm{N}\right.$, $129^{\circ} 22^{\prime} 44.34^{\prime \prime} \mathrm{E}$, about $20 \mathrm{~m}$ in elevation and about $3.5 \mathrm{~km}$ from the river mouth), which discharges into the East Sea (= Sea of Japan). The cave developed in the massive limestone of the Ordovician Geunnam Formation of the Joseon Supergroup (Kim et al., 2010). The cave is mostly horizontal, and its main passage and branches are about $330 \mathrm{~m}$ and $540 \mathrm{~m}$ long, respectively, making the total length of the cave about $870 \mathrm{~m}$. The first $270 \mathrm{~m} \mathrm{sec}-$ tion of the main passage from the entrance is open to tourists, and the remaining sections are closed to public access to protect the cavern environment. It contains numerous stalactites, stalagmites, columns and curtains around three large cavern lakes. The material of the present study was collected at the third cavern lake, in the protected area about $300 \mathrm{~m}$ from the cave entrance (Fig. 1).

Specimens were collected by one of us (Y.G. Choi) using a plankton net with a $110 \mu \mathrm{m}$ mesh size, mostly at the edge of the lake at depths of $60-80 \mathrm{~cm}$ (the lake has a maximum depth of about $7 \mathrm{~m}$ ). The substrate was muddy, containing calcium carbonate deposits. One female and two males were collected on 9 March 2002, and three females and three males were collected on 9 June 2002. The water temperature was $14.3^{\circ} \mathrm{C}$ (March) and $16.0^{\circ} \mathrm{C}$ (July), pH 8.1 (March) and 7.6 (July) and conductivity $-54 \mathrm{mV}$ (March) and $-30 \mathrm{mV}$ (July).

Co-occurring troglobionts included Pseudocrangonyx coreanus Ueno (Amphipoda), Orthomorphella sp. (Diplopoda), Kaolinonychus coreanus coreanus (Suzuki) (Opillionida), Gallosiana sp. (Grylloblattodea: Insecta) and Myotis daubentoni ussuriensis Ognev (Chiroptera: Mammalia).

Appendages were dissected and mounted in glycerol and drawn with the aid of a camera lucida. Carapaces are stored dry in micropalaeontological cavity slides. Carapaces used for SEM investigation were coated with gold before being photographed with a JEOL 5800 LV scanning electron microscope.

The holotype and allotype are deposited in the National Institute of Biological Resources (NIBR), Korea (Numbers: NIBRIV0000244931 and NIBRIV0000244932). The paratypes are deposited in the collections of the Department of Biological Science, Daegu University (Numbers: DB40029 to DB40032). 


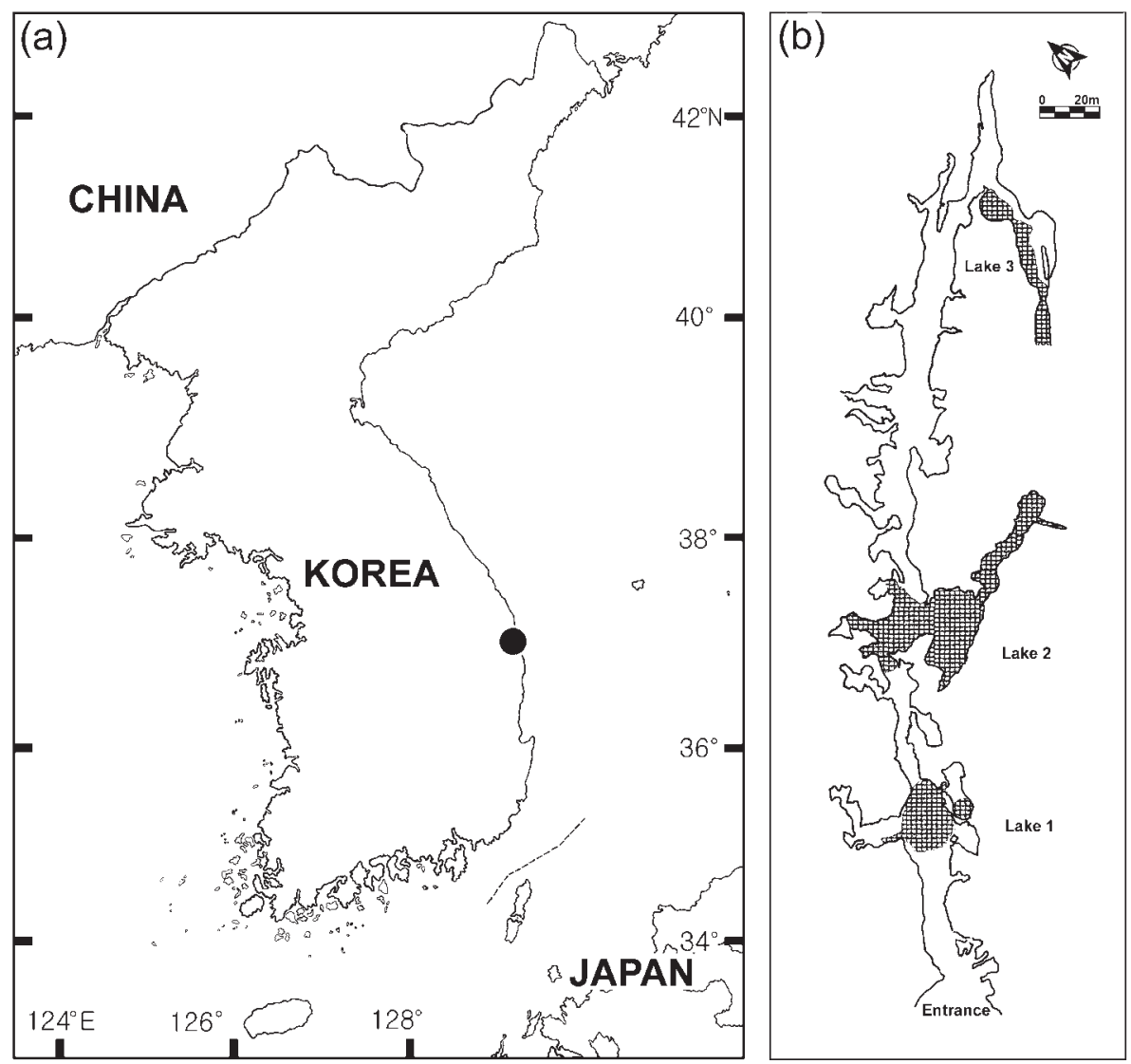

Fig. 1. (a) Location and (b) map of Seongryu Cave, showing main cavern and three cavern lakes.

\section{SYSTEMATIC DESCRIPTION}

Superfamily Cytheroidea Baird, 1850

Family Limnocytheridae Klie, 1938

Subfamily Timiriaseviinae Mandelstam, 1960

(emended by Colin \& Danielopol, 1978)

Genus Frambocythere Colin, 1980

Frambocythere relicta $\mathrm{n}$. sp.

(Figs 2-4)

Derivation of name. From the Latin, relictus, meaning left behind.

Diagnosis. Female: ventral and dorsal margins sub-parallel in lateral view, well-developed central sulcus, weakly developed anterior sulcus. Anterior margin rounded, posterior margin more truncated. Left valve with small caudal process and three stout, stubby spines on postero-ventral margin. 'Raspberry-type' micropustule ornamentation well developed. Male: slightly smaller than female, posterior less inflated than female. Hemipenis with large, straight, distal lobe with rounded tip, upper ramus hookshaped and small, lower ramus flattened with straight distal margin, rounded proximal margin. Copulatory process slender and simple.

Type material. Holotype: dissected male (NIBRIV0000244931). Allotype: dissected female (NIBRIV0000244932). Paratypes: dissected male (DB40029), dissected female (DB40030), whole female (DB40031), whole male (DB40032).
Type locality. The third cavern lake from the entrance of Seongryu Cave in Uljin-gun Province in South Korea, $36^{\circ} 57^{\prime}$ $21.7^{\prime \prime} \mathrm{N}, 129^{\circ} 22^{\prime} 45.37^{\prime \prime} \mathrm{E}$.

Description. Carapace (Fig. 2) length and height - see Table 1. Female - lateral view sub-rectangular, dorsal and ventral margins more or less parallel. Ventral margin slightly sinuous. Dorsal margin straight in anterior half, slightly convex in posterior half. Anterior margin equally rounded. Postero-dorsal margin angular, postero-ventral margin rounded. Two sub-parallel sulci running from dorsal margin downwards and slightly towards anterior margin, one positioned at mid-length, one shorter sulcus in anterior quarter (indicated with arrows on Fig. 2B). Surface of valves strongly ornamented with 'raspberry-type' micropustules. Left valve with small caudal process and three short, stubby spines on postero-ventral margin. Right valve overlaps left. Hinge lophodont, with cardinal teeth on left valve; anterior tooth gently curved and about 1.4 times length of posterior tooth. Dorsal view rounded posteriorly, triangular anteriorly, with strong indentation at midsulcus. Maximum width at posterior third.

Male smaller than female with much less inflated posterior region. Left valve with one or two short, stubby spines. Dorsal view with maximum width just posterior of central sulcus.

Antennule (Fig. 3A) six segmented. First segment elongate, without setae. Second segment elongate with one long seta on ventral edge, and setules along dorsal edge. Third segment small, slightly elongate with one short, stout apical-dorsal seta. Fourth segment 

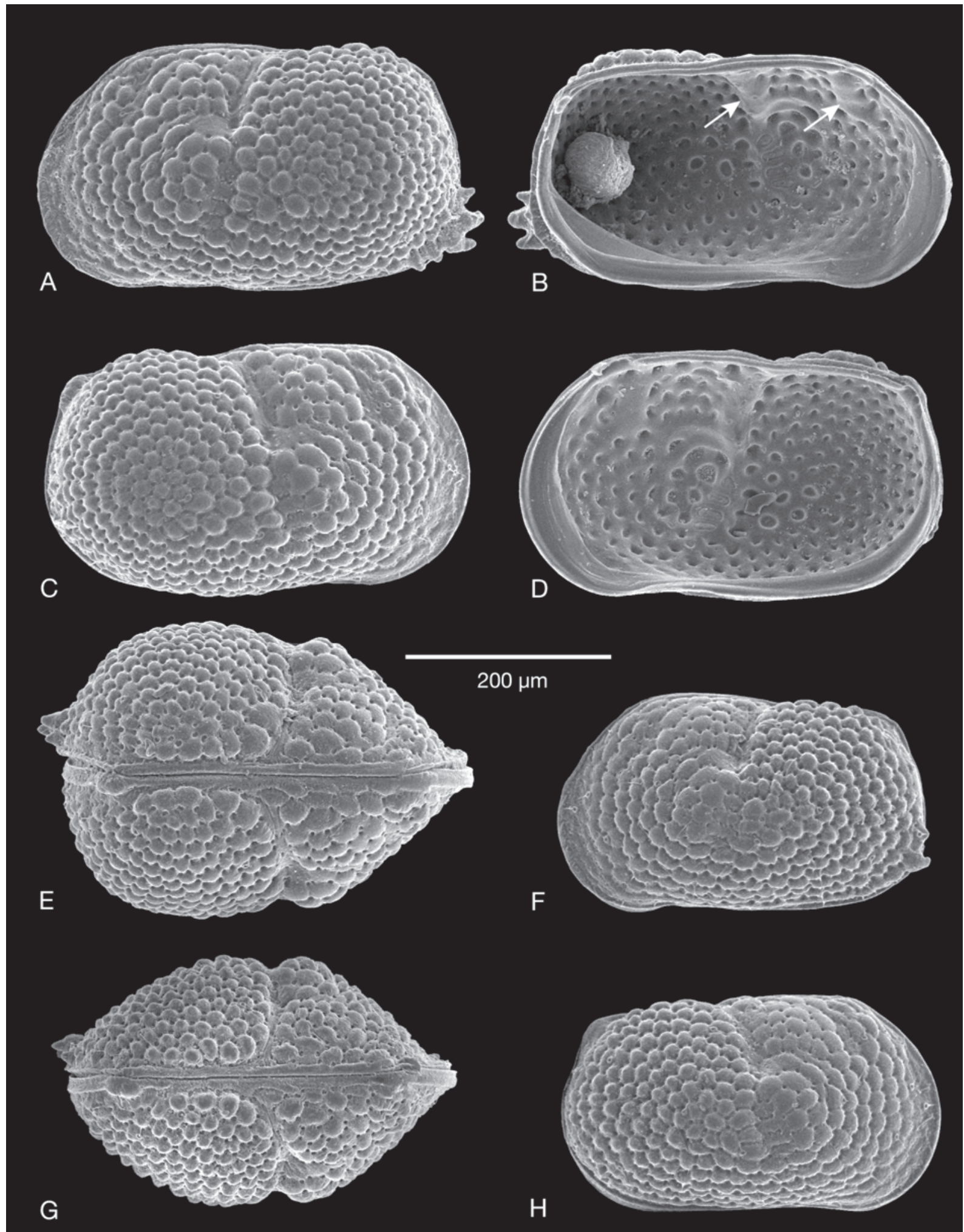

Fig. 2. Frambocythere relicta n. sp.: A, external view of female left valve (DB40030); B, internal view of female left valve (arrows indicate sulci) (DB40030); C, external view of female right valve (DB40030); D, internal view of female right valve (DB40030); E, dorsal view of whole female carapace, anterior to right (DB40031); F, external view of male left valve (DB40029); G, dorsal view of whole male carapace, anterior to right (DB40032); H, external view of male right valve (DB40029). 

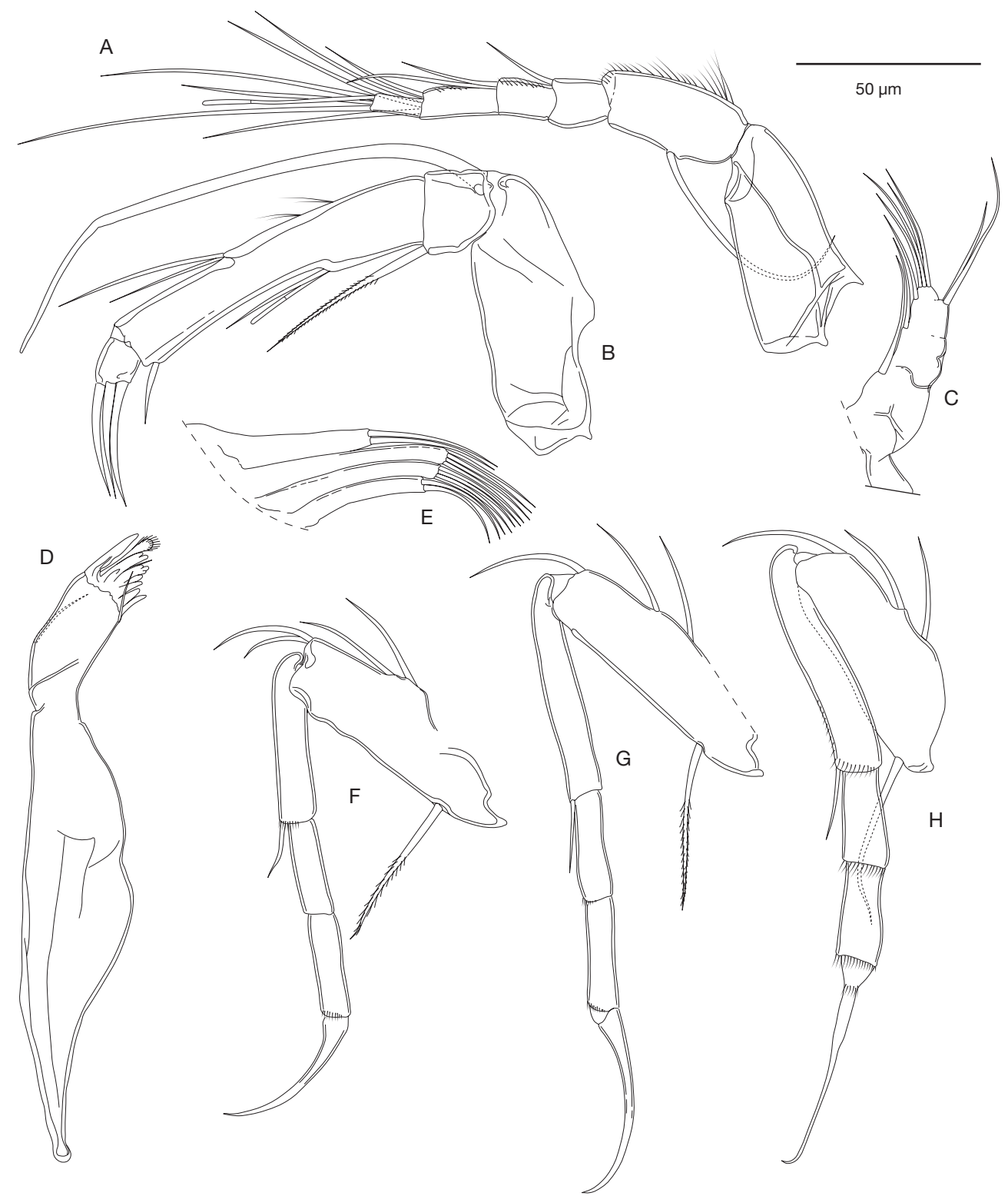

Fig. 3. Frambocythere relicta n. sp.: A, antennule (NIBRIV0000244931); B, antenna (NIBRIV0000244931); C, mandibular palp (NIBRIV0000244932); D, mandibular coxa (NIBRIV0000244931); E, palp and endites of maxillula (NIBRIV0000244932); F, fifth limb (NIBRIV0000244932); G, sixth limb (NIBRIV0000244932); H, seventh limb (NIBRIV0000244932).

Table 1. Measurements of type specimens.

\begin{tabular}{|c|c|c|c|}
\hline NIBRIV0000244931, male (holotype) & 385 (RV) & 225 (RV) & - \\
\hline NIBRIV0000244932, female (allotype) & 410 (RV) & 229 (RV) & - \\
\hline DB40030, female (paratype) & 415 (RV) & 241 (RV) & - \\
\hline DB40031, female (paratype) & 402 (RV) & - & $287(\mathrm{Cp})$ \\
\hline DB40032, male (paratype) & 379 (RV) & - & $244(\mathrm{Cp})$ \\
\hline
\end{tabular}

$\mathrm{RV}$, right valve; $\mathrm{Cp}$, whole carapace.

longer, but thinner than third segment, with two apical-dorsal setae of differing lengths. Fifth segment longer than fourth, with three long and one shorter apical setae. Sixth segment small and elongate, with three long setae of differing lengths and long aesthetasc $y a$.
Antenna (Fig. 3B) with four segments. First segment elongate, tapering slightly distally. Spinneret seta long and thin, reaching to end of apical claws. Second segment quadrate, with one, stout, long apical-ventral seta. Third segment very elongate, with 

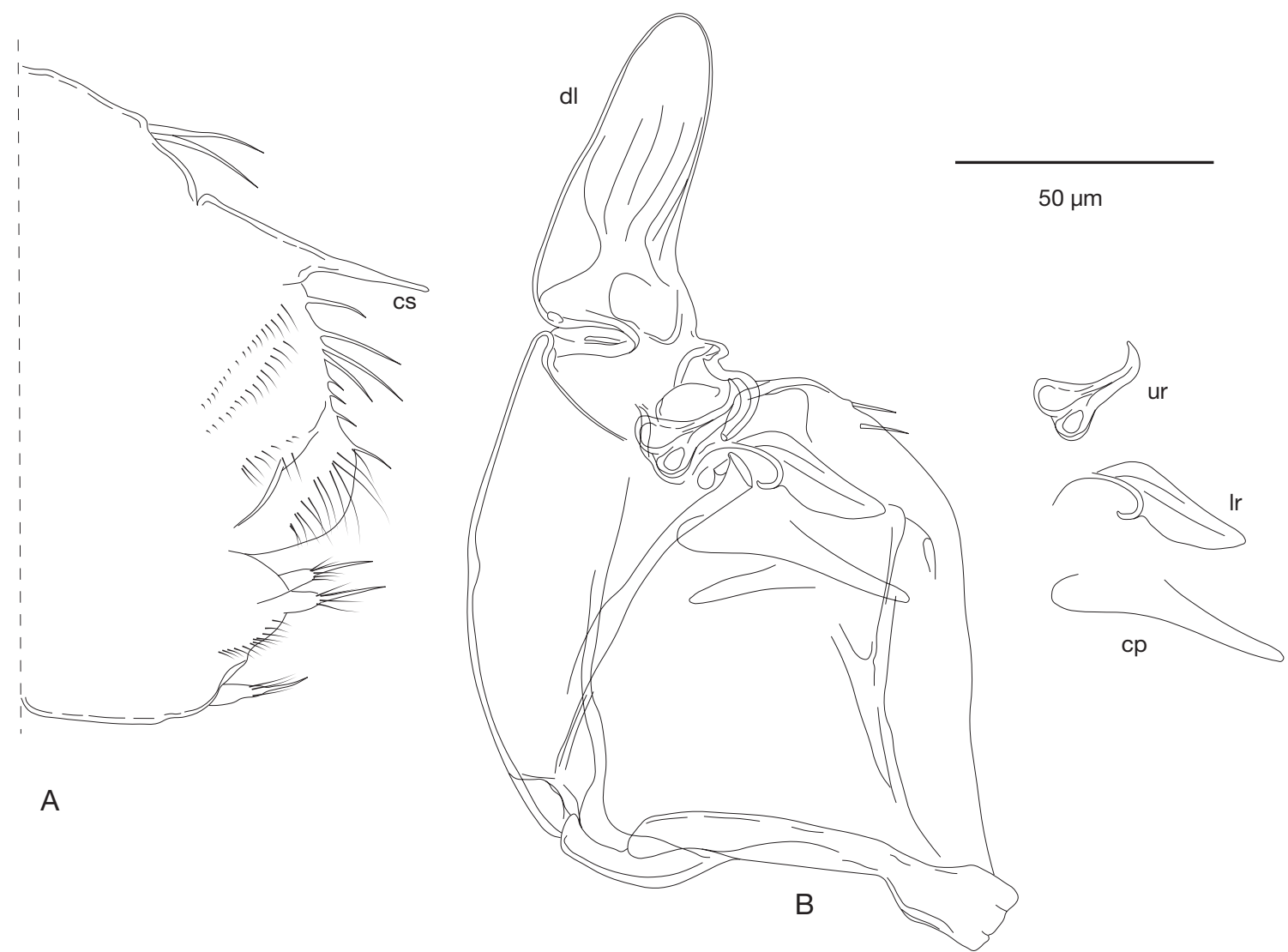

Fig. 4. Frambocythere relicta n. sp.: A, posterior of female body (NIBRIV0000244932) (cs, caudal seta); B, hemipenis (NIBRIV0000244931) (dl, distal lobe; ur, upper ramus; lr, lower ramus; cp, copulatory process).

aesthetasc and seta on ventral edge, two setae on dorsal edge, and one short, stout apical-ventral seta. Fourth segment quadrate with three curved apical claws.

Mandibular palp (Fig. 3C) with four indistinct segments. First segment elongate, with branchial plate on outer edge and one stout, long seta on inner edge. Second segment quadrate, with one stout, long seta on inner edge. Third segment indistinctly divided from second segment, with two apical setae on outer edge and one apical seta on inner edge. Fourth segment short and small, indistinctly separated from third segment, with four apical setae. Mandibular coxa (Fig. 3D) with seven teeth, and large, distally rounded setulous seta between two largest teeth. Small subapical seta on outer edge of coxa.

Maxillula (Fig. 3E) with elongate palp and three slender and longer endites, which gently curve towards inner edge. Palp with two curved, long, stout apical setae. Second and third endites both with four apical setae. First endite with two apical setae.

Fifth limb (Fig. 3F) with four segments. First segment elongate with one long sub-proximal posterior seta, two setae on anterior edge and two apical-anterior setae. Second segment slender and elongate, with one short apical-anterior seta. Third and fourth segments approximately equal in length, fourth segment with short curved claw, with wide basal section, gradually tapering distally.

Sixth limb (Fig. 3G) with four segments, longer than fifth limb. First segment elongate with one long sub-proximal posterior seta, two setae on anterior edge and one apical-anterior setae. Second segment slender and elongate, with one short apical-anterior seta.
Third and fourth segments approximately equal in length, fourth segment with short curved claw, with wide basal section, tapering gradually distally. Claw longer than claw of fifth limb.

Seventh limb (Fig. 3H) with four segments, all of which are more robust and wider than those of fifth and sixth limbs. First segment elongate with one long sub-proximal posterior seta, two setae on anterior edge and one apical-anterior seta. Second segment elongate, with one short apical-anterior seta. Third and fourth segments approximately equal in length. Claw of fourth segment long, mostly straight along length, with exception of distal tip; claw with subtriangular base, narrow middle section and thinner final section.

Rear of female body (Fig. 4A) with finger-like caudal seta and numerous long, stout setules protruding below. Caudal ramus with two posterior, and one anterior stout, hirsute setae.

Hemipenis (Fig. 4B) with large basal capsule, with rounded outer edge, and straighter inner edge. Distal lobe large and elongate, not significantly curved, with evenly rounded tip. Upper ramus small, consisting of a rounded base tapering and curving distally to form a hook-shape. Lower ramus elongate with straight upper edge and curved lower edge, and with well-defined tip. Copulatory process slender, tapering gradually along length with blunt tip.

Remarks. The carapace shape of Frambocythere relicta n. sp. is most similar to that of Frambocythere gr. tumiensis (Helmdach, 1978) reported from the Thanetian (upper Paleocene) of the Paris Basin (Ducasse et al., 1985). Both species have a weakly developed anterior sulcus, and the general lateral outline and ornamentation 
are very similar. Frambocythere relicta n. sp. is slightly less elongate than Frambocythere gr. tumiensis, and the latter has only very small spines on the postero-ventral margin of the left valve.

Frambocythere valeroni Tambareau, 1991 (in Tambareau et al., 1991) from the Ypresian (early Eocene) of SW France is also similar to Frambocythere relicta n. sp.; both $F$. valeroni and Frambocythere relicta n. sp. have a weakly developed anterior sulcus. However, F. valeroni is more elongate than Frambocythere relicta $\mathrm{n}$. sp. with a maximum height in lateral view anterior of mid-length.

\section{DISCUSSION}

\section{Hypogean Ostracod Fauna of South Korea}

Previous surveys of seven limestone caves during the 1960s in the northeastern part of South Korea revealed three hypogean species/ subspecies of ostracods: Pseudocandona morimotoi (McKenzie, 1972), Cavernocypris coreana coreana (McKenzie, 1972) and Cavernocypris coreana elongata (McKenzie, 1972). All three taxa are potentially endemic to the Korean Peninsula, although at least one, C. coreana elongata, is not restricted to cave environments as it was later found in spring runoffs at the surface (Chang et al., 2012). Frambocythere relicta n. sp. increases the known cave ostracod fauna of South Korea to four species, and is the first representative of the superfamily Cytheroidea in the hypogean realm of South Korea.

\section{The Kovalevskiella-lineage}

The genera Frambocythere, Kovalevskiella and Rosacythere Colin, 1980 (in Colin \& Danielopol, 1980) form the Kovalevskiellalineage, characterized by a small-sized carapace ( $0.5 \mathrm{~mm}$ or less), ornamentation in 'rosettes' or 'raspberry-type' micropustules, an inverse hingement with positive elements on the left valve, the right valve overlapping the left, no, one or two near-vertical sulci, and marked sexual dimorphism with the females having a welldeveloped brood pouch (Colin \& Danielopol, 1980). The lineage has a history stretching back to the latest Bajocian (Middle Jurassic), approximately 168 Ma ago, represented by a Rosacythere species from the Paris Basin (Oertli, 1957; Colin \& Carbonel, 1996). Living representatives consist of five species of Kovalevskiella, found in the hypogean realm of central and southeastern Europe and Turkey (Danielopol, 1965; 1969; 1970; Colin \& Danielopol, 1980; Karanovic, 2003; Özuluğ \& Yaltalıer, 2008). Later, the Kovalevskiella-lineage was included in the Kovalevskiella-Abrotocythere Group, which includes the genera Kovalevskiella, Rosacythere, Frambocythere, Abrotocythere Zhao, 1987, and Dolekiella Gidó et al., 2007 (Gidó et al., 2007).

The genus Frambocythere was erected for fossil species with a 'raspberry-type' ornamentation, two near-vertical sulci on each valve, an inverse overlap and strong sexual dimorphism, originally for specimens from the Late Maastrichtian of northern Spain (Colin, 1980, in Colin \& Danielopol, 1980). Subsequently, other fossil species have been included in the genus, ranging from the Albian (Colin, 1993; Colin \& Dépêche, 1997) through to the Lutetian (middle Eocene) (Tambareau, 1984; Tambareau et al., 1991), with a very wide palaeobiogeographical distribution from central Africa (Colin, 1993; Colin \& Dépêche, 1997), SW Europe, China (Hou et al., 1978), Iran (Vaziri Moghaddam et al., 2010) and India (Bhandari \& Colin, 1999; Whatley \& Bajpaj, 2006). Frambocythere species usually had a bisexual mode of reproduction, although asexual populations are known (Tambareau et al., 1991). The living Korean Frambocythere species greatly extends the stratigraphical range by approximately $40 \mathrm{Ma}$ to the present, and increases the known (palaeo-)biogeographical range by approximately $1400 \mathrm{~km}$ to the far east of Eurasia.

The genus Kovalevskiella is similar to Frambocythere, but differs from it in that it has only one sulcus on each valve. It is known from lacustrine deposits in the late Oligocene and Miocene of Western Europe and the Pliocene of the Paratethys (Carbonel et al., 1986). Living representatives are now restricted to the hypogean realm of central and southeastern Europe, and Turkey. Males have not been reported for any of the species in the genus and it is considered to be entirely parthenogenetic. The genera Kovalevskiella and Frambocythere are considered to be more closely related to each other than to other genera in the group (Gidó et al., 2007; Colin, 2011).

The anterior sulcus of Frambocythere, the feature that separates the genus from Kovalevskiella, is rather weakly developed in $F$. relicta n. sp. and two of the younger fossil forms, $F$. gr. tumiensis, and $F$. valeroni, compared with other fossil species. The anterior sulcus is probably a plesiomorphic character within the Frambocythere-Kovalevskiella lineage, which became reduced and eventually lost in some taxa, giving rise to the genus Kovalevskiella. The difference between Frambocythere species with a reduced anterior sulcus and Kovalevskiella species is, therefore, rather small. However, the anterior sulcus is a persistent character in numerous species/subspecies of Frambocythere, and has a good fossil record dating back to the Cretaceous, long before species without it, i.e. Kovalevskiella spp., appeared. Its presence, even when weakly developed (and its absence in Kovalevskiella), can therefore be used to help identify phylogenetic lineages within the group, and so we consider it to be a useful generic character.

\section{Comparison of Frambocythere relicta n. sp. with living Kovalevskiella ssp}

The living Korean Frambocythere species provides an opportunity to compare the appendages of these two genera for the first time. Of the five extant Kovalevskiella species, the antennule of Kovalevskiella cvetkovi (Danielopol, 1969) is most similar to that of Frambocythere relicta n. sp.; other species either have fewer antennule segments (Kovalevskiella rudjakovi (Danielopol, 1969)) or one fewer apical seta on the fourth antennule segment (Kovalevskiella phreaticola (Danielopol, 1965), Kovalevskiella bulgarica (Danielopol, 1970) and Kovalevskiella dani Karanovic, 2003). The antenna of Frambocythere relicta n. sp. most closely resembles that of $K$. bulgarica, as other Kovalevskiella species have one fewer seta on the anterior margin of the second endopodal segment, including $K$. cvetkovi. The mandibular palp of Frambocythere relicta n. sp. is similar to those of three Kovalevskiella species, K. phreaticola, K. cvetkovi and K. bulgarica; the mandibular palps of $K$. dani and $K$. rudjakovi have fewer setae on the second and third segments. The other appendages of Frambocythere and Kovalevskiella are very similar, although $K$. phreaticola appears to have only one seta on the dorsal margin of the first segments of the sixth and seventh limbs (Danielopol, 1965) (two setae in Frambocythere relicta n. sp. and other Kovalevskiella species). As no males of Kovalevskiella are known, a comparison of the male sexual organ of Frambocythere cannot 
be made. However, the general structure of the male sexual organ does resemble those of the other two extant Timiriaseviinae genera, Metacypris Brady \& Robertson, 1870 and Dolekiella Gidó et al., 2007.

Overall, all features of the female appendages of Frambocythere relicta $\mathrm{n}$. sp. appear in at least one extant Kovalevskiella species, confirming that these two genera are very closely related. Additionally, all features in Kovalevskiella appear in Frambocythere relicta n. sp; thus, Frambocythere is not excluded from being the ancestor of Kovalevskiella.

\section{Relict species or atavistic characters?}

There are two scenarios that could potentially explain the presence of an extant Frambocythere species after the apparent extinction of all other species of the genus. The first is that it is a true survivor of the genus Frambocythere and, while other species of the genus succumbed to extinction tens of millions of years ago, a lineage survived to the present day. The other scenario is that its anterior sulcus of the carapace, the morphological feature that separates Frambocythere from the genus Kovalevskiella, is an atavistic feature that has resurfaced in the extant Kovalevskiella. This would require that Frambocythere is the ancestor of Kovalevskiella, which a detailed analysis of the appendages does not exclude (see above). It would also require the species to have reverted from asexual to sexual reproduction, as all Kovalevskiella species, both fossil and extant, are parthenogenetic. Such a reversion to sexual reproduction would also be an atavistic feature, and is something that has not been recorded in ostracods. Two atavistic features occurring in the same species (the re-emergence of the anterior sulcus and the reversion to sexual reproduction) is considered to be unlikely, and so we favour the first scenario, i.e. Frambocythere relicta $\mathrm{n}$. sp. is a relict species of the genus, and not a Kovalevskiella species with atavistic features. Molecular comparisons of Frambocythere relicta n. sp. with extant Kovalevskiella species could test this hypothesis.

\section{From the epigean to hypogean realm}

Danielopol $(1970 ; 1980)$ hypothesized that the hypogean species of the Kovalevskiella-lineage living today in central and southeastern Europe, and Turkey are relicts of an ostracod fauna that lived in surface waters during the Tertiary. While some surface species became extinct, others migrated to the hypogean realm; Kovalevskiella is postulated to have penetrated the subterranean realm between the Lower Oligocene and Lower Pleistocene (Danielopol, 1980). Carbonel et al. (1986) further suggested that this migration to the hypogean realm was facilitated by their morphology, broad ecological ranges and parthenogenetic mode of reproduction. We hypothesize that a similar scenario may have occurred in the genus Frambocythere; it too was originally widely distributed and long ranging, and was an epigean taxon, but today, it is apparently restricted to Korea in a hypogean habitat. However, Frambocythere relicta n. sp. is a sexual species, suggesting that at least in this case, parthenogenesis was not an important pre-adaptation for colonizing the hypogean realm.

The long gap (approximately $40 \mathrm{Ma}$ ) between the youngest fossil Frambocythere known (an epigean species) and the living hypogean specimens could indicate that Frambocythere entered the hypogean realm an extremely long time ago, and thus 'disappeared' from the epigean fossil record. However, data on fossil freshwater ostracod taxa in eastern Asia are scarce, and so we cannot rule out that younger epigean Frambocythere species existed in this region. We are, therefore, unable at present to estimate the timing of the colonization of the hypogean realm by the genus to any satisfactory degree.

\section{ACKNOWLEDGEMENTS}

We thank the Natural Heritage Division of the Cultural Heritage Administration and the Office of Seongryu Cave, Ulijin County, Republic of Korea for their help with this study. We also thank Dan Danielopol (University of Graz) and Dave Horne (University of London) for their useful reviews and comments. This work was partly supported by the project of Discovery of Indigenous Species from Korea sponsored by the National Institute of Biological Resources (NIBR) under the Ministry of Environment, Korea.

\section{Manuscript received 1 December 2011 Manuscript accepted 13 January 2012} Scientific Editing by Alan Lord

\section{REFERENCES}

Bhandari, A. \& Colin, J.-P. 1999. Ostracodes limniques des sédiments inter-trappéens (Maastrichtien terminal-Paléocène basal) de la région d'Anjar (Kachchh, Etat de Gujarat), Inde: systématique, paléoécologie et affinités paléobiogéographiques. Revue de Micropaléontologie, 42: 3-20.

Carbonel, P., Colin, J.-P., Danielopol, D.L. \& Londeix, L. 1986. Kovalevskiella (Ostracoda, Timiriaseviinae), genre à mode de vie benthique depuis l'Oligocène, son adaptation à la vie interstitielle. Geobios, 19: $677-687$.

Chang, C.Y., Lee, J. \& Smith, R.J. 2012. Nonmarine ostracods (Crustacea) from South Korea, including a description of a new species of Tanycypris Triebel (Cyprididae, Cypricercinae). Zootaxa, 3161: 1-19.

Colin, J.-P. 1993. An early representative of the genus Frambocythere Colin, 1980: Frambocythere pustulosa (Grekoff, 1957) from the Albian of Zaire. Journal of Micropalaeontology, 12: 170.

Colin, J.-P. 2011. From light to darkness: from Frambocythere Colin, 1980 to Kovalevskiella Klein, 1963 (Limnocytheridae, Timiriaseviinae). Joannea Geologie und Paläontologie, 11: 44-47.

Colin, J.-P. \& Carbonel, P. 1996. Middle Jurassic record of the limnic ostracod genus Rosacythere (Limnocytheridae, Timiriaseviinae): implications to the origin and evolution of the Kovalesvskiella group. Journal of Micropalaeontology, 15: 187-191.

Colin, J.-P. \& Danielopol, D.L. 1978. New data on the systematics of the Limnocytheridae (Ostracoda, Cytheracea). Geobios, 11: 563-567.

Colin, J.-P. \& Danielopol, D.L. 1980. Sur la morphologie, la systématique, la biogéographie et l'évolution des ostracodes limniques Timiriaseviinae (Limnocytheridae). Paléobiologie Continentale, 11: 1-52.

Colin, J.-P. \& Dépêche, F. 1997. Faunes d'ostracodes lacustres des bassins intra-cratoniques d'âge albo-aptien en Afrique de l'Ouest (Cameroun, Tchad) et au Brésil: considérations d'ordre paléoécologique et paléobiogéographique. Africa Geoscience Review, 4: 431-450.

Danielopol, D.L. 1965. Nouvelles données sur les ostracodes d'eau douce de Roumanie: Cordocythere phreaticola n. g. n. sp., Eucypris petkovskii n. sp. Limnocytherini et Metacyprini nouvelles tribus de la sous-famille Limnocytherinae Sars, 1925. Annales de Limnologie, 1: 443-468.

Danielopol, D.L. 1969. Notes sur la morphologie et la systematique de la sous famille Limnocytherinae Sars (Crustacea, Ostracoda). Annales de Speleologie, 24: 129-142.

Danielopol, D.L. 1970. Sur la morphologie, l'origine et la répartition du genre Cordocythere Dan. (Ostracoda-Cytheridae). In Académie de la République Socialiste de Roumanie (Ed.), Livre du centenaire Emile G. Racovitza. Bucarest, 287-300. 
Danielopol, D.L. 1980. An essay to access the age of the freshwater interstitial ostracods of Europe. Bijdragen tot de Dierkunde, 50: 243-291.

Ducasse, O., Guernet, C. \& Tambareau, Y. 1985. Paléogène. In Oertli, H.J. (Ed.), Atlas des ostracodes de France. Mémoires Elf-Aquitaine, 9, Pau: $257-311$.

Gidó, Z., Artheau, M., Colin, J.-P., Danielopol, D.L. \& Marmonier, P. 2007. Description of the stygobitic crustacean Dolekiella europea gen. nov. sp. nov. (Ostracoda, Limnocytheridae) from southern France. Vie et Milieu, 57: 109-116.

Helmdach, F.-F. 1978. Nichtmarine Ostrakoden aus der Spanischen Oberkreide. Berliner Geowissenschaftliche Abhandlungen, Reihe A, 3: 156-161.

Hou, Y., Ho, J. \& Ye, C. 1978. The Cretaceous-Tertiary ostracods from the marginal region of the Yangtze-Han River Plain in Central Hubei. Memoir of the Nanjing Institute of Geology and Paleontology, 9: 129-206 [In Chinese].

Karanovic, I. 2003. The genus Kovalenskiella Klein, 1963 (Crustacea, Ostracoda) from the ground waters of Greece, with description of Kovalenskiella dani n. sp. and a key to world species. Spixiana, 26: 227-242.

Kim, L., Woo, K.S., Kim, B.H., Park, J.S., Park, H.Y., Jeong, H.J. \& Lee, J.H. 2010. Scientific significances of the Seongryu Cave (Natural Monument No. 155). Mun Hwa Jae (Annual Review in Cultural Heritage Studies), 43: 236-259 [In Korean].

Klein, L.N. 1963. Novye ostrakody iz Verkhnepliotsenovykh i Antropogenovykh otlozheniy Azerbaydzhana [New ostracods from Upper Pliocene and Quaternary deposits of Azerbaijan]. Sbornik Nauchno-teknicheskoy Informatsii, Voprosy Geologii, Aznii DN, 2: 91-97.
Mandelstam, M.I. 1960. In Luebimova, P.S., Kazmina, T.A. \& Reshetnikova, M.A. (Eds), Ostracoda from Mesozoic and Cenozoic deposits of the West-Siberian lowland. Trudy Vsesoyuznogo Neftyanogo Nauchno-Issledovatelskogo Geologo-Razvedochnogo Instituta (Vnigri), Novaya Seriya, 160: 1-427.

McKenzie, K.G. 1972. Results of the speleological survey in South Korea 1966. XXII. Subterranean Ostracoda from South Korea. Bulletin of the National Science Museum, Tokyo, 15: 155-166.

Oertli, H.J. 1957. Ostracodes. In Bernard, F., Bizon, J.-J. \& Oertli, H.J. (Eds), Ostracodes lacustres du Bathonien du Poitou (Bassin de Paris). Bulletin de la Société Géologique de France, séries 6, 6: 753-770.

Özuluğ, O. \& Yaltalıer, S. 2008. A preliminary study on the Rezve stream and a new record for Ostracoda (Crustacea) fauna of Turkey. IUFS Journal of Biology, 67: 93-96.

Tambareau, Y. 1984. Les ostracodes du 'Montien Continental' de Hainin, Hainaut, Belgique. Revue de Micropaléontologie, 27: 144-156.

Tambareau, Y., Gruas-Cavagnetto, C., Feist, M. \& Villatte, J. 1991. Flores et faunes continentales ilerdiennes du versant sud de la Montagne Noire et de la Montagne d'Alaric. Revue de Micropaléontologie, 34: 69-89.

Vaziri Moghaddam, H., Safari, A., Shariari, S., Taheri, A. \& Khazaei, A.R. 2010. Introducing the clastic-carbonate and red clastic sediments of Maastrichtian in High Zagros region (Semiron-Ardal). Journal of Science University of Tehran, 36: 103-117.

Whatley, R.C. \& Bajpaj, S. 2006. Extensive endemism among the Maastrichtian non-marine ostracoda of India with implications for palaeobiogeography and 'out of India' dispersal. Revista Espanola de Micropaleontologia, 38: 229-244.

Zhao, Y.-H. 1987. On Abrotocythere quinquicornis Zhao gen. et sp. nov. Stereo-Atlas of Ostracod Shells, 14: 111-114. 